\title{
Literature and Cinema: The Military vs. the People in the Hetero-Visiotypes and Hetero-Imagotypes of the 1974 Portuguese Revolution
}

\begin{abstract}
Based on imagological theory and authors such as Leerssen and Beller, I will study images of the Portuguese 25 April Revolution in the nineties and at the beginning of the twenty-first century, namely in the Luso-French-Brazilian Sérgio Tréfaut's documentary Outro país (2000) and Lídia Jorge's recent novel Os memoráveis (2014), focusing on the implications of using different media and codes. Both documentary and novel have in common the same research method, in the sense that both look for temporally distant testimonies of the event. In a more fictional way, but under the same postmodern vision of History, Jorge, like Tréfaut, offers the reader fragments of an unfinished historical episode that we can only grasp through successive versions and perspectives. Since the novel opposes fiction to the presumed realism of the interviews and to a hybrid-genre film, the documentary, I will compare Jorge's literary verbal medium, codes, and structure with Tréfaut's languages, in order to identify the perspectives and strategies employed to realize the thesis of each work.
\end{abstract}

Keywords: 1974 Portuguese Revolution, hetero-imagotypes, hetero-visiotypes, imagology, Lídia Jorge, memory, Os memoráveis

In this article, I set out to analyse works - both documentary and literary - about memories, as we can see in their titles: Outro país: Memórias, sonhos, ilusões ... Portugal 1974/1975 [Another Country: Memories, Dreams, Illusions ... Portugal 1974/1975] and Os memoráveis [The Memorable People]. In particular, I aim to establish a dialogue between the documentary and the novel, showing the different kinds of attention paid to the role of the working class and the role of the military as agents of the 25 April Revolution, and to their subsequent images. In both cases, I will try to determine in which way the different images are associated with the levels of the text, since, by coincidence, as we shall see, both the documentary and the novel are structured on three levels.

In fact, in Outro país, Sérgio Tréfaut selects photos and films from foreign photographers and filmmakers who came to Portugal to cover the Revolution for international media; the film director mixes those fragments with interviews with 
authors and with working-class people that he intentionally shot twenty-five years later. As for Lídia Jorge, she opposes the three different parts of her novel in order to provide the reader with the backdrop to the first part's closed narrative and to question it, in the second part, using the interviews that Ana Maria Machado, the transfrontier protagonist, does with prominent April army captains. In the last part, she offers a third version of the event with the brief documentary "plot" that the journalist Ana Maria Machado must write. Here, one can observe the selection she really makes from the interviews and the interviews she explicitly chooses in order to preserve her intended lyrical tone.

\section{Memories and images}

In Memory, History, Forgetting, the philosopher Paul Ricoeur deeply analyses memory as a median level between time and narrative and its ties with History, and postulates the existence of three kinds of memory: collective memory, which "recalls common and public memories of the communities to which we belong"; individual memory, defined by the "living memory of individual persons"; and a distinct kind of memory, that of people's close relations, that is, the memories of the "people who count for us and for whom we count [that] are situated along a range of varying distances in the relation between self and others" (Ricoeur, 2004, 131).

As memory is linked to History and to collective memory, in order to study images of the April Revolution it is useful to resort to the typology presented by Ricoeur so as to put into context the different testimonies and analyse them according to imagology theory (Dyserinck 1996; Leerssen 2003; Beller and Leerssen 2007; Sánchez Romero 2005; Fischer 1987). Given the different nature of my corpus, I chose to merge different conceptions present in the inter- and transdisciplinary scope of imagology. Literary imagology is one of the most important perspectives of comparative literature. It focuses on the origin and function of the features of other countries and people as they are textually written and presented in literary works, essays, and so on. Considering its heuristic potential, and following Pageaux (1981), who defended a comprehensive concept, and searched for an understanding, of culture in general, I include in my study of foreigners' images of Portugal those that can be found in a "given text, in a literary work or even in a culture" (Machado and Pageaux 2001). ${ }^{1}$

1 Translations of Portuguese excerpts in this article are my own. 
So, by approaching the foreigner images that the documentary Outro país creates, I will talk about images as almost direct representations of reality, rather than literary images, which are "a set of ideas about foreigners included in a process of literarization and socialization” (Machado and Pageaux 2001, 50). Depending on who looks or is looked at, one could talk about auto- and hetero-image, as Hugo Dyserinck (1966) did within literary context. But, considering the visual nature of the documentary images, it would be better to resort to the less common, but perhaps more productive concept of the visiotype, which Pörksen (1997) defines as an optical representation of political events in print and television. Thus, although there is an epistemological difference between the documentary and these types of media (print and television), I suggest mixing Dyserinck's terminology with Pörksen's, thereby creating the terms "auto-visiotype" and "hetero-visiotype” for the study of foreigners' images of Portuguese people in Sérgio Tréfaut's documentary.

As for the literary corpus (Os memoráveis), the issue of terminology is simpler, not only because the study of the foreigner in Lídia Jorge's novel is established by the imagology's subject, but also because Manfred Fischer (1987) coined the concept of the imagotype as a specifically literary concept - an option endorsed by Sánchez Romero (2005) both because it was a linguistic creation and less misleading than an image. At the same time, this concept covers both groups of images that directly represent reality, the prejudice and the stereotype. By merging Fischer's (1987) terminology with that of Dyserinck (1966), we could use the terms "auto-" and "hetero-imagotype" - notions already validated in some German literature (e.g. Siebenmann 2003).

\section{Images of Portugal through different memories and genres}

The foreigner's view of Portugal - in particular of the Portuguese Revolution of 25 April 1974 and its unravelling through time - dominates the dialogue with the Other that these works both portray, although this is done more intensively in the documentary. Facing the same historical reality - the end of the Fascist regime and of the Colonial War, and the beginning of democracy - several hetero- and auto-images (lato sensu) of the episode and of its main agents were assembled and created. Firstly, in the nineties, the Luso-French-Brazilian Sérgio Tréfaut shot an impressive documentary that he named suggestively Outro país: Memórias, sonhos, ilusões ... Portugal 1974/1975 (2000); secondly, Lídia Jorge, a Portuguese writer, published a historical novel entitled Os memoráveis (2014). Since this is 
not a case of semiotic transposition - or, at least, one cannot prove from the novel that Lídia Jorge knew her predecessor - it can be said that these two works are independent. Nevertheless, they have the same historical subject in common, since, quoting Claus Clüver's essay “Inter textus/inter artes/inter media," they both represent "aspects of reality captured by the senses" $(2006,14)$ and they are a consequence of different interpretative communities. It is exactly these different interpretative communities that are of interest for comparative literature, since in the documentary we deal with foreigners' perspective on the Portuguese - filtered by a three-nationality director - and in the fictional book we deal with representations of the country - which bring together images made by an American character with images made by Portuguese agents of the Revolution. In my comparative analysis of both of these works, I will try to study the relationship between these two sources, of which the documentary is closer to reality and the novel conditioned by fiction.

There are two main aspects of these images (lato sensu), filtered by memory, that are worth highlighting. The first has to do with the fact that both the documentary and the historical novel take as their starting point historical happenings and one particular episode that affected Portuguese collective memory. The second has to do with the publication context of each of the works, since in both cases, the publication date is symptomatically connected to a cultural context of celebration: a quarter of a century and forty years after the Revolution, respectively. In Outro país, this need of remembering and of keeping the memory alive is an implicit one, while in Os memoráveis it emerges from the plot, which suggests the need of recalling the past precisely in order to avoid the excesses of forgetfulness (Ricoeur 2004).

Thus, with different reception contracts and with different media, both works are a product of memory lato sensu, also reinforcing collective memory. The works talk about the past in a fictional way or with a similar discourse to what, in his Introduction to Documentary, Bill Nichols (2010) called the discourses of sobriety. By doing so, these two works are the product of the selection and thoughtful combination of the events with each other, and thus necessarily biased, as Todorov (1995) suggests in his book about the abuses of memory. This combination and orientation is even more clear in the documentary because of the author's "claims about his relationship with the historical world," although he cannot "separate himself clearly from the narrative strategies or from the fascination of fiction" (Nichols 2000, 18).

Although in different ways, both the documentary and the novel appeal to individual and collective memories, with Os memoráveis still adding the memories of one's close relations, mentioned at the beginning. And if it is well known that Ricoeur established the differences between these three kinds of memory 
in the context of History and historiography, it is also certain that neither Outro pais nor the novel have historiographical pretensions. Yet they are deeply and consciously related to History and to its links with memory. Under the same postmodern vision of History, and in spite of Lídia Jorge's fictional approach, she and Tréfaut offer the reader flashes of an unfinished historical episode that one can only grasp through successive versions, focuses, and perspectives. The different memories and the distinctive kinds of memories are the subjects of this plural perspective.

In Sérgio Tréfaut's documentary, the first hetero-visiotypes of Portuguese people we see are the product of research conducted in archives and studios from all over the world, and show reactions to their Revolution; the anonymous testimonies express their joy, excitement, and the will to be part of it. These recordings include individual memories as well, either from filmed or photographed people, who years later remember and assess the Revolution, or from film authors who share their interpretation of a moment in Portuguese history that truly fascinated them.

As for the dialogue between the three kinds of memories in Lídia Jorge's novel, the individual ones stand out. They express the personal memories of a US ambassador and of the seven agents of the Portuguese Revolution, and they are an important contribution for the final documentary that Ana Maria Machado, the reporter-protagonist, creates about 25 April 1974 and for the collective memory it cultivates. Finally, the novel explores a curious link between individual and close relations' memories, as the seven agents of the Revolution who are interviewed by the reporter were also her father's friends in the past, as can be seen in a photo he hid. Therefore, since the people in this picture were also her childhood points of reference, they still matter for her, and so do their memories (Ricoeur 2004. 131). In fact, this picture is the starting point for the documentary, as we will see later on.

Thus, by combining a plurality of memories, both authors construct several hetero-visiotypes and hetero-imagotypes of the Revolution and of the way it was welcomed in Portugal and abroad. Their respective semi-foreign (with a triple nationality) and native (through the main character that lived in the US for five years) perspectives are expressed through hetero-visiotypes and hetero-imagotypes representing two main groups: the people and the military.

It is worth clarifying, as we shall see later on, that in both works the concept of foreigner is not always absolutely clear, although there is a constant thin line between those who observe and those who are observed, producing an imagological look in the moment that the I looks at the Other and enrols in a conversation with him and, eventually, with himself (Pageaux 2005). 


\section{The documentary}

In Outro país, Sérgio Tréfaut presents a very coherent sequence of foreign photos and films shot during the 1974 Portuguese Revolution. Although it is a LusoFrench-Brazilian who signs off the documentary, its photos, films, and reports were previously signed off by other foreign journalists, reporters, or filmmakers who presented their hetero-imagotypes of Portuguese people, at the time and later.

By taking advantage of the inherent audio-visual possibility that a documentary provides, the author's purpose is also to give an idea of the intensity of recording activity. Additionally, he wants to show how directors and photographers mediated the way the Portuguese sensed the Revolution, the assessment made by their foreign contemporaries, and how they themselves felt twenty-five years later about the changes in the country. This results in a very intercultural documentary, as we have the images of directors, journalists, and photographers from countries like Sweden, France, the US, and others. But one should not forget that, although the audience comes into direct contact with the images and discourses of those foreign authors, all the material that makes up the documentary is subjectively filtered by the camera of the Luso-French-Brazilian Sérgio Tréfaut. We could thus say that the documentary has a second-language degree, as the material used is not directly the Portuguese reality but rather a selection of it made using foreigners' work. In addition, we could argue that it is not Tréfaut who works on what Sella Bruzi $(2000,125)$ called the first-language degree, where one finds "the dialectical conjunction of a real space and the filmmakers that invade it." Rather, this definition of documentary fits perfectly the behaviour of the previous photographers and interviewers, as they are in fact the ones who dealt with reality and invaded it. It is also this two-degree framework that presents us with two levels of otherness. The first level is that of the foreign directors' images, of the evaluation they made, and of some of the testimonies they recorded in the past and revisited years later. The second level can be seen in Tréfaut's documentary and in the selection he makes from others' input. In reality, we only listen to the Luso-French-Brazilian director at the beginning of the film (since he chooses to hide himself when the selected images that his predecessors captured in the past are displayed) and at the end of the documentary, when he is interviewing the directors of the works he has fragmentarily displayed.

The mediation of those individual memories through a representation modality based on observation - which, as Bill Nichols (2010, 72-78) states, minimizes the director's presence - will not reduce his subjectivity or his partiality. Even so, the set of records we are shown, in a sort of redundant way, constructs a living memory for his contemporaries and their successors. Simultaneously, it globally 
freezes a revolutionary version of this historical period and the political manipulations that Portugal was subjected to, from abroad.

All the excitement and trust in a new life for Portugal can be seen in the first emotions and testimonies that were recorded from immediately after the day of the Revolution until 1 May, Labour Day in Europe. Civilians and military talked loudly and freely as they had never done before, and with a new energy.

Throughout the film, the hetero-visiotypes of the Portuguese gradually abandon their focus on the military to concentrate on the working class and their statements. As for the soldiers, even though they are not quoted, their role is commented by foreign authors' reflexive memory, because, as privileged witnesses of History, not only did they know what they had recorded, but also what was going on behind the scenes. Thus, this is the only way we gain contact with the soldiers' actions and with the inner conflicts they were facing. We do not see or hear their testimonies. That part of History is told, not shown, by foreign directors, as if the working class, that we keep seeing, had not noticed what was happening. The people's hope was so great that they could only seize the good part of History.

Although this is the trend the images appear to follow, the reporters' individual memories present more critical and distant hetero-visiotypes when speaking in the present, about the way they felt during those days, and afterwards, when they reflect on the role of the Portuguese Revolution. Where the people vs military opposition is concerned, the reporters' discourses fill the void that images create, for in their interpretations they refer to the differences within the army and the destruction of its power. Yet, this does not diminish the power and the relevance that Sérgio Tréfaut attributes to the working class, as we can see in his selection of hetero-visiotypes: throughout the whole film, the working-class presence is constant. We see it and we hear it in a recursive way. People are always present and, in its simplicity, it is their way of feeling and sensing the historical movement that we are shown.

Very gradually, the documentary introduces a significant shift in the heterovisiotypes that are shown: we begin to face an analytical review of the development of the Revolution. In fact, this second part focuses on a later period that moves away from the initial euphoria - where people declared enthusiastically they would do everything to support the Revolution, hand-in-hand with the army - and shows us that the collective images disappeared and that the soldiers are not present anymore, as if the past alliance had died. The only survivors were old people, lonely people, and disappointed people. In their individual memories, enthusiasm and hope belong to the past, at which they look with nostalgia. Looking at the camera, they state they can barely recall and identify the benefits of the Revolution. 
As for the directors' individual memories about the enormous changes that occurred after 1975, they reflect the same fluctuation from joy to sadness, although we cannot ignore the fact that these views are strongly ideological. We could even say the directors are mainly leftists, as the foreign directors and photographers believed in a potential change based on the Revolution's ideology and the workers' power. In the director Robert Kramer's opinion, conservative Europe could not allow a revolutionary country in the continent's western corner. More universally, Portugal was allowed to live a utopia, but it could not last. In spite of its regretful feeling, Kramer's lucid synthesis is a kind of conclusion to the documentary.

From what we have seen in Outro pais, the main focus of the camera is on the working class, its poorness, its hopes, and its deluded fight for a better world. The army became part of this mission, but then it disappeared from daily life and the working class was once again left on its own.

To sum up, there is some redundancy and homogeneous meaning in the way the hetero-visiotypes from different observers complement each other. But, at the same time, there is no doubt about the authors' will and capacity to influence the viewer, nor about Tréfaut's selection and the structured speech he composes and articulates through editing and montage (Gifreu 2011). The final product, apart from presenting the levels of the two narratives, also presents two antagonistic worlds. One is a simple and native world that acts and interprets, and is mainly composed by the people and shown through foreigners' eyes. The other is recorded by the documentary director and composed by foreign filmmakers and photographers who observe and analyse the historical reality and share their individual memories with him.

Moreover, taking into account Tréfaut's interviews, we could postulate a third level in the documentary: an independent level whose analytical style can be added to the historical narrative of the first documentary level. The disappointed visiotype the interviewers display is the intellectual counterpart of what the people's testimonies stated in the second part of the documentary, where we saw them reliving their individual memories.

Thus, when Sérgio Tréfaut builds his image of Portuguese people in the revolutionary period, combining selected testimonies from other films, reports, and photos, he builds a coherent hetero-visiotype of the country in revolutionary times. As it is always the case with images, this is a hetero-visiotype naturally biased and manipulated by the foreign authors and by Sérgio Tréfaut's personal observation and ideology (Ricoeur, 2004, 14). However, although part of the historical analysis matches the facts, or the official History, we cannot say it is a consensual image of Portugal. It is nonetheless an image of an important group from southern Portugal, defined by a leftist ideology. In fact, we only see one side 
of History, as is implicit in the title Outro país [Another Country], which does not intend to make a generalization (e. g. "the country"). Nevertheless, it can still be said that these hetero-visiotypes are in line with the collective memory that the country preserves - although it cannot be claimed that they represent the whole country.

\section{The novel}

In Lídia Jorge's novel, we face the same recursive and redundant way of creating hetero-imagotypes that we found in the hetero-visiotypes of the documentary, since we also have the same story told from multiple perspectives, by different characters, and, similarly, on three different narrative levels.

The interest of comparing the documentary and the novel has its grounds mainly in the way each author constructs their work and in the fact that Os memorâveis distances itself from a certain realism in Outro país. The inherent fictionality of the novel allows for a freer protocol, which the writer uses to create, in the second and third parts, a kind of roman-à-clef, giving nicknames to the historical characters that the protagonist interviews. In general, the author reconstructs historical agents, but these links to reality almost prevent the reader from credibly identifying the historical characters.

Forty years after the Revolution, in a kind of fight against oblivion, Lídia Jorge wants to remember a historical episode that is ignored by the younger generation born after the Revolution that brought freedom to the country. In a novel constructed in three parts, she presents three different visions of the revolutionary period. In the first one, “The Fable," a US ambassador orders the protagonist, a CBS reporter, to film the first episode - about the Carnation Revolution - of the series Awaking History. In the hetero-imagotype he creates, it is the tolerance he saw in the revolutionary period that is astonishing and, along with the carnations that flourished on military weapons, it is that surprising tolerance that makes those times luminous. Like the interpretations presented in Sérgio Tréfaut's documentary, the US ambassador also mentions international politics and the impossibility of having a socialist government in Western Europe. But, quite differently from the directors' interpretations, he, or Frank Carlucci - the person behind the fiction, who was the ambassador to Portugal from 1974 to 1977 - presents himself as part of that History, belonging to the sector that prevented a Communist regime.

Thus, in "The Fable" - a name that suggests an imaginative synthesis - we deal with a special memory that is individual and authorized because it is presented as based on a political experience in Portugal and in the international con- 
flict the ambassador had to fight. So, what was told in Outro país is now revealed by a character that refers to a political actor. According to the ambassador's interpretation, the end of the revolutionary period was a matter of time and patience (Jorge 2014, 18) and "it would come, without sacrificing the Portuguese people and without turning them into guinea pigs of socialism in order to set an example of disgrace for the Europeans" (Jorge 2014, 30).

His individual memories recall the wonderful Portuguese people and their peacefulness as well as their poverty, further in line with the hetero-visiotypes of the Portuguese people that we saw in Sérgio Tréfaut's documentary. However, he arrives at a synthesis that exceeds what the documentary-maker said about the people, because now they are also violent.

Poor people without algebra, with no letters, with fifty years of dictatorship on their back, their feet tied to the ground, and suddenly a coup d'état happens, they all come onto the street screaming, each one with its own hallucinations, project, and interest, threatening each other, body to body, face to face, lots of them carrying weapons in their hands, and in the end they insult themselves, they beat themselves up, they arrest themselves, and they do not kill themselves. (Jorge 2014, 17)

Regarding the people vs military opposition, it may seem that, at the beginning of the novel, the military are not so relevant and that, in fact, all the ambassador's enthusiasm is channelled into the collective. However, at a certain point, he rethinks this and observes that these anonymous people have the imprint of one of the April army captains, whose civil name is Vasco Lourenço (Jorge 2014, 28). It is worth noting that, unlike the other two parts, in "The Fable" we are often given the real names of historical characters.

In a strikingly different way, the following two parts of the book focus mainly on the military movement, while the people's enthusiasm is only recalled by the military actors. And, if we think about Ricoeur's three attributions of memory, we realize that, in the framework chosen by the Portuguese reporter for her documentary, she introduces the memory of close relations - the third kind of memory, between individual memory and collective memory, which is the memory that belongs to our family and friends (Ricoeur 2004, 131, 163).

In fact, in the long second part, symptomatically named "Into the Fable's Heart," the reporter Ana Maria Machado uses a photo that was shot in August 1975 in a restaurant that close friends called "Memories." It is a picture of a dinner with her parents, seven soldiers previously opposed to the regime, and other persons. In different ways, these memorable characters were prominent figures of the April Revolution, or close to them, and they are part of Ana Maria Machado's youth memories because they were all her father's friends and often visited her house. Taking advantage of these memories of close relations and guided by that photo, 
a relic from the past, the reporter intends to explore their memories to construct her narrative of those times.

In the interviews she and her team develop, she does not introduce herself as António Machado's daughter, and the interviewees do not recognize her because she was too young back then. At the same time, her individual memories of those times made her reject that past for family reasons. Thus, she works anonymously and, during the interviews, she does not want to restore the close relationship they had in the past, when they were part of her family group. That intimacy is part of her secret. Consequently, the interview testimonies - we could say the auto-imagotypes they present - appeal to their individual memories and they only become memories of close relations when the photo is shown and they remember their past intimacy.

Reading all the individual answers, we face mixed feelings towards individual memories and auto-imagotypes of Portugal, its past and present. On the one hand, we have the reporting of a glorious moment that everyone took part in, especially the military. On the other hand, there is a shared feeling of frustration due to lost hopes for the country's future, the lack of recognition, and the fact that, to a certain extent, the military were forgotten. It is all about memory and forgetting. And those images of Portugal, here described by the April protagonists, are not monolithic, but rather dual and, in that sense, coincide with the discourse of foreigners and the hetero-visiotypes they offered in Sérgio Tréfaut's documentary. Despite the difference in voice (foreigners and natives, respectively), they all sense the Revolution as one made out of joy, but also of disillusion.

In this respect, it is worth highlighting what there is in common between the content of those auto-imagotypes, seen here as an image that one has of the world as opposed to the auto-imagotype that derives from a hetero-imagotype. The interviews - the frame employed to construct Ana Maria Machado's documentary - act against oblivion and intend to "fulfil a plan of memory reconstruction" (Jorge 2014, 239). In order to achieve that - on the third level of the novel, that is in the documentary plot, which the reporter designs lyrically - all the historical apologies and lies we read in the interviews with the military are deleted so that a mythical image of the Revolution is created. This is the idealized solution the reporter chose in order to begin the documentary television series Awaking History - a title symptomatically linked with the idea of collective memory.

Thus, in her documentary, Ana Maria Machado and the camera operator idealistically focus on what needs to be registered in order to remember and to feed collective memory: the notion of a downtime, which only restarted at the beginning of the coup d'état, with the sound of footsteps from people rising up, the emergence of soldier figures, the fragments of testimony from the interviewed military recalling the Colonial War, the feeling of a miracle unfolding, and the 
determination to do no harm. The sound is complemented with pictures from key moments of the military march, the distribution of flowers that took place, and the crowd that came together on the day of Revolution to support the soldiers. Finally, we see the image of the general who took over power and of the captain who laid down the Revolution strategy - neither of their names is mentioned. From this last image there is a transition to the photo of the memorable figures in the restaurant, and then to the images of their youth, full of joy, and then again to a recent picture of the same heroic captain, shot near the sea. And, because this man is a myth, he does not talk. At the end, there is a fragment of the US ambassador's speech in the Senate highlighting all that had happened in the previous two years without any bloodshed: "A unique case in the world's history" (Jorge 2014, 341). These hetero-imagotypes - as we call them, considering the distancing and estrangement of the CBS reporter - are a contribution to collective memory in the sense that they reinforce it. Somehow, it is the History of concrete winners that the documentary emphasizes, differing in this point from Outro pais, where the all agents were anonymous and common people.

Contrary to traditional history, the heroes are nameless. Along with its postmodern conceptualization, Ana Maria Machado's documentary produces a kind of idealized and coherent synthesis of what the fragmented second part, "In the Heart of the Fable," had represented from multiple perspectives, for she is conscious of the impossibility of defining or stabilizing historical interpretations. In addition to the documentary coherence, there is another aspect one cannot miss: the sense of originality and brightness that spans the novel from the hetero-imagotype of Portugal, created by the US ambassador, to its adoption by the migrant reporter.

As a whole, despite the multiple photos it shows, the documentary emphasizes the military's action, not only because most of the interviewees are military, but also because the whole novel is a tribute to the five hundred members of the military that were involved and must be remembered.

As we can see, in the writing of the documentary, there is a large difference between the individual and close memories recorded and the final plot. In this mimetic representation of the reporter's work we also find two other traits of the documentary. First, there is the difference between what one records and what is delivered to the television channel. As Ana Maria Machado explains, this difference remains "the substance that we hold in our hands forever, to enlighten our lives" (Jorge, 2014, 301). In a sense, everything she learned from the interviews with her father's former friends made her understand better her father's frustrations and face her personal memories about her family and about the country from which she had fled five years before. Second, there is the delay in the story, which the reporter only writes six years after the interviews, thus reflecting the 
time she needed to understand the country she had left. Her hybrid status as a Luso-American reporter favours her curiosity and also her knowledge of Portugal in its singularity. The documentary she lyrically designs is the answer to her father's accusation that she had invaded his friends' lives (Jorge 2014, 326). After being censored by her father, because of her supposedly unethical behaviour and her supposed modifications to what she hears with her biased standpoint, Ana Maria Machado at last seems to understand the reasons for that generational disenchantment and for the impossibility of finding a definitive historical interpretation. Symptomatically, she finishes her own testimony by acknowledging that the luminous entity had gone long ago, and that it would take "forty years, a hundred years, or the time that might be deemed necessary, in order to unravel what really had happened" (Jorge 2014, 342).

\section{In conclusion}

Through the reporter's final analysis, Lídia Jorge’s historical novel joins Sérgio Tréfaut's documentary in the search for the memories of others: mainly foreigners, in Outro pais, and mainly natives, in Os memoráveis. Both works started with the foreign perspective - a real one and a fictional one, respectively - and then they move, in a certain sense, to the Portuguese one, despite Sérgio Tréfaut's triple nationality and the fact that the novel's Portuguese protagonist has been abroad for quite some time. Imagologically, the status of the director and of the protagonist has ensured a degree of distancing and estrangement from the observed culture, moving away from what would be the native's perspective.

Altogether, these authors' representations of Portugal feed the collective memory of its recent History. Despite the delusion of the memories of close relations, Ana Maria Machado's final documentary script is a sort of anthem to the April military, now more personalized. The military acts as a strong imagotype, auto- and hetero-, depending on who looks at it, in the fight against oblivion. In Outro país, on the other hand, we see only an anonymous military and the way it guides the working class and helps them bring about the Revolution. As we have seen, the work focuses on the effect that the Revolution had on people and on the general feeling of disappointment that followed. Consequently, we could also say that, while Os memoráveis is an anthem to the April military, Outro pais is an anthem to the people.

Despite the non-fictional cinematographic mode and the historical novel being different types of media, both genres recollect different memories from different people in order to approach Portuguese visio- and imagotypes, regard- 
less of the contract each medium makes with its audience. The different forms of the people vs military opposition that these authors represent are, partially, a consequence of the perspective each one adopts: the longue durée in the novel and a closer look in the documentary. Nevertheless, regardless of the paths they follow, both messages are closely linked to reality and complement each other in the visio- and imagotypes of Portugal, (re)presenting the period and groups they choose to highlight: people in the documentary and the military in the novel. In spite of the melancholic feeling of the interviewees, we notice a common philia in the foreign culture of Portugal in the sense that Machado and Pageaux defined it - that is, as a positive perspective on a more or less foreign culture, within a culture that is itself considered positively (2001, 61-62).

\section{Works cited}

Beller, Manfred, and Joep Leerssen, eds. Imagology: The Cultural Construction and Literary

Representation of National Characters: A Critical Survey. New York: Rodopi, 2007. 17-32.

Bruzi, Sella. New Documentary: A Critical Introduction. London and New York: Routledge, 2000. Clüver, Claus. “Inter textus/inter artes/inter media." Aletria 14 (July-December 2006): 11-41. Dyserinck, Hugo. “Zum Problem der 'images' und 'mirages' und ihrer Untersuchung im Rahmen der Vergleichenden Literaturwissenschaft.” Arcadia: Zeitschrift für Vergleichende Literaturwissenschaft 1 (1966): 107-120.

Fischer, Manfred S. "Literarische Imagologie am Scheideweg: Die Erforschung des 'Bildes vom anderen Land' in der Literatur-Komparatistik." Erstarrtes Denken: Studien zu Klischee, Stereotyp und Vorurteil in englischsprachiger Literatur. Ed. Günther Blaicher. Tübingen: Narr, 1987. 55-70.

Gifreu, Arnau. “The Interactive Multimedia Documentary.” Hipertext.net 13 (2011). http://www. upf.edu/hipertextnet/en/numero-9/interactive-multimedia.html (13 January 2017).

Jorge, Lídia. Os memoráveis. 2nd ed. Lisbon: Publicações Dom Quixote, 2014.

Leerssen, Joep. “Images - Information - National Identity and National Stereotype.” Imagologica. 2003. https://pt.scribd.com/document/65373329/Images-Joep-Leersen (15 February 2019).

Machado, Álvaro Manuel, and Daniel-Henri Pageaux. Da literatura comparada à teoria da literatura. 2nd ed. Lisbon: Presença, 2001.

Nichols, Bill. Introduction to Documentary. 2nd ed. Bloomington and Indianapolis: Indiana University Press, 2010.

Pageaux, Daniel-Henri. “Une perspective d'études en littérature comparée: L’Imagerie culturelle.” Synthesis 8 (1981): 169-185.

Pageaux, Daniel-Henri. “Littérature comparée et comparaisons.” SFLGC (Vox Poetica). 15 September 2005. http://www.vox-poetica.org/sflgc/biblio/comparaisons.html (12 January, 2017).

Pörksen. Uwe. Weltmarkt der Bilder: Eine Philosophie der Visiotype. Stuttgart: Klett-Cotta, 1997. Ricoeur, Paul. Memory, History and Forgetting. 2000. Trans. Kathleen Blarney and David Pellauer. Chicago and London: University of Chicago Press, 2004. 
Sánchez Romero, Manuel. “La investigación textual imagológica contemporánea y su

aplicación en el análisis de obras literárias.” Revista de Filología Alemana 13 (2005): 9-28.

Siebenmann, Gustav. Suchbild Lateinamerika: Essays über interkulturelle Wahrnehmung.

Tübingen: Niemeyer, 2003.

Todorov, Tzvetan. Les Abus de la mémoire. Paris: Arléa, 1995.

Tréfaut, Sérgio. Outro país: Memórias, sonhos, ilusões ... Portugal 1974/1975. Costa do Castelo Filmes, 2000. DVD. https://www.youtube.com/watch?v=c8LjRCUbOMQ\&feature=youtu.be (12 January 2017).

Ana Maria Machado has a PhD in Portuguese Literature (University of Coimbra) and she is assistant professor at the same university. She has written several essays on medieval literature, teaching literature, digital literature, and imagology. 
